IOSR Journal of Engineering

Apr. 2012, Vol. 2(4) pp: 824-830

\title{
Evaluation of Green Supply Chain Management Strategies Using Fuzzy AHP and TOPSIS
}

\author{
P. Muralidhar ${ }^{1}$, Dr K Ravindranath ${ }^{2}$, Dr V Srihari ${ }^{3}$ \\ 1,3 (NICMAR's -CISC, NAC Campus, Kondapur post Hyderabad-500084) \\ ${ }^{2}$ (Professor, Dept of Mechanical Engineering, SVU College of Engineering, TIRUPATI.)
}

\begin{abstract}
This paper presents a new decision making approach for group multi-criteria evaluation for green supply chain management strategies, which clubs green procurement, manufacturing, green service to customer and environmental management process with order allocation for dynamic supply chains to cope market variations. More specifically, the developed approach imitates the knowledge acquisition and manipulation in a manner similar to the decision makers who have gathered considerable knowledge and expertise in procurement domain. Fuzzy-AHP method is used first for evaluation of GSCM strategies and weights are defined which are qualitatively meaningful. Thereafter, using fuzzy TOPSIS method, the criteria application is quantitatively evaluated for order allocation among the selected strategies. As a result, the approach generates decision-making knowledge, and thereafter, the developed combination of rules for order allocation can easily be interpreted, adopted and at the same time if necessary, modified by decision makers. To demonstrate the applicability of the proposed approach, an illustrative example is presented and the results analyzed.
\end{abstract}

Keywords: Green supply chain Management (GSCM) strategy prioritization, fuzzy AHP, fuzzy TOPSIS, knowledge, multicriteria, and group decision.

\section{Introduction}

Nowadays, among various supply chain-related activities, the procurement of goods and services is playing an increasingly important role as a result of the globalization of the economy. Purchasing expenses can consume as much as $60 \%$ or more of business' revenues. In many settings, supplier selection is a crucial strategic decision that has long-term impacts on a company's profitability and efficiency [1,2]. This paper presents a novel approach for automatic fuzzy based knowledge acquisition, which defines strategies selection process with order allocation. More specifically, the developed approach imitates the knowledge acquisition and manipulation in a manner similar to the decision makers who have gathered considerable knowledge which are qualitatively meaningful. Thereafter, using fuzzy logic, the criteria application is quantitatively evaluated. As a result, the approach generates decision-making knowledge, and thereafter, the developed combination of rules for supplier selection with order allocation can easily be interpreted, adopted and at the same time if necessary, modified by decision makers.

\subsection{Case study}

The current case study is mainly focusing on XYZ Cement manufacturing company. The cement manufacturing company is focused on producing fly-ash based cement. The fly ash used is waste product from thermal power plant which reduces carbon footprints, energy efficient and environment friendly cement. For this purpose the company wants to give highest priority to green procurement, green manufacturing practices, Good customer service and Environment compliance. The hierarchy structure is shown in Figure 1 with three levels $[3,8]$. 
IOSR Journal of Engineering

Apr. 2012, Vol. 2(4) pp: 824-830

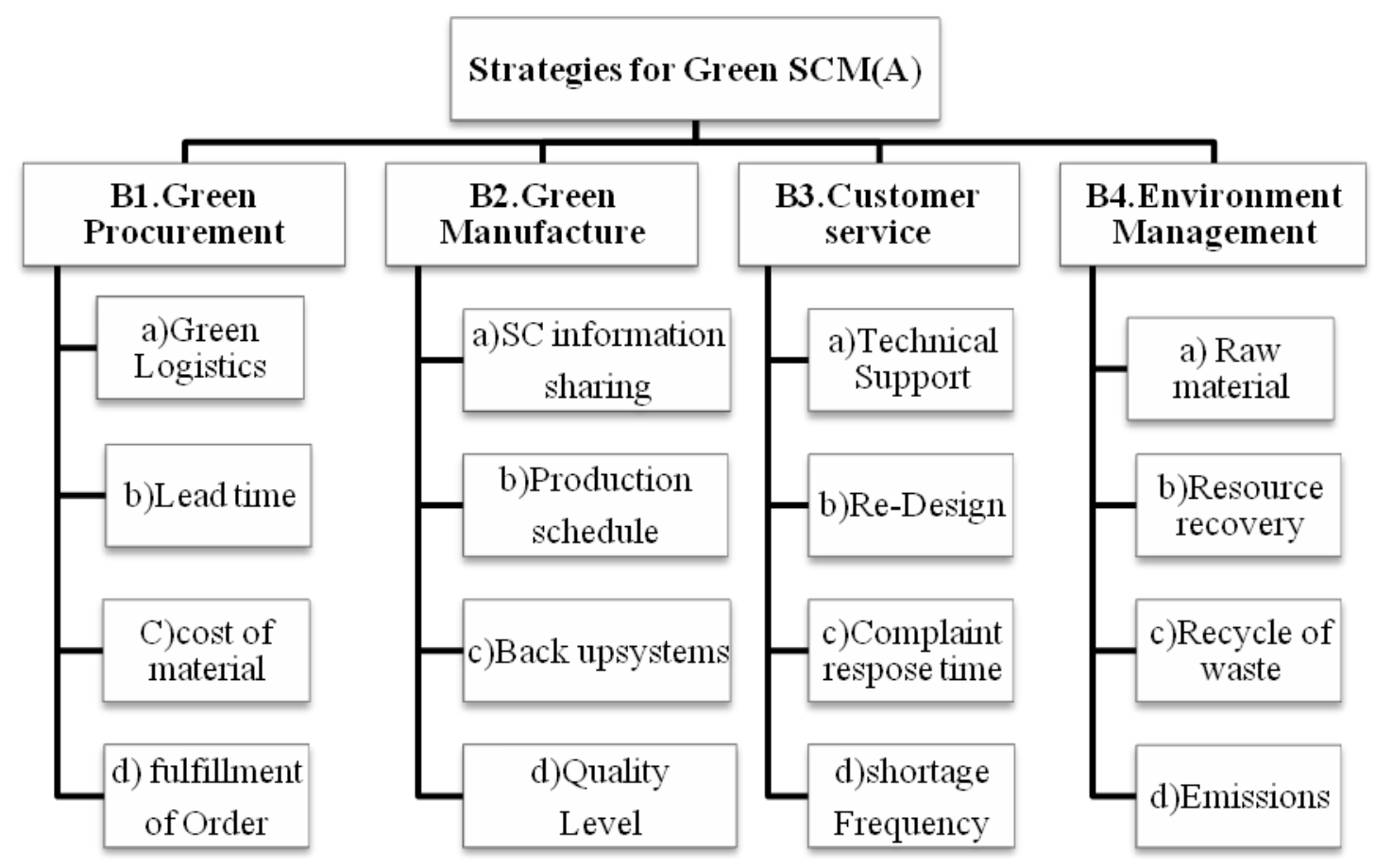

Fig1. GSCM Measurement Indicators [3]

The rest of the paper is organized as follows:

Section 2 presents state of art of strategy prioritization/selection problem.

Section 3 presents problem description and proposed TOPSIS approach.

Section 4 illustrates some of the experimental results.

Section 5 concludes the paper with some comparison of results obtained by using FAHP[6].

\section{Prioritization of GSM strategies using AHP, Fuzzy-AHP and TOPSIS}

\subsection{THE AHP process}

A number of research works have been published in the last decades emphasized the strategic importance of the GSCM process and evaluated the relative importance of the most used [4,5]selection Main criteria and sub criteria of strategies selected. Van der Rhee et al. [10] explored how executives' trade-off amongst various dimensions when selecting a supplier. An empirical study is presented to assess the GSCM strategies with sixteen measurement indicators using a market utility-based approach (DCA). Moreover, Amid et al. [17] developed a fuzzy weighted additive and mixed integer multi objective linear programming model for the supplier selection problem under price breaks that depend on the sizes of order quantities.

\subsection{The Fuzzy-AHP process Factors}

Fuzzy AHP is an extension of synthesized AHP method [4,5,6] where the fuzziness of the decision making is considered [10]. Initially AHP and FAHP scales are defined for pair wise comparison matrices and then measurement Indicators are defined $[7,8]$, Level I, level II pair wise comparison matrices are established for obtaining the priority weights these alternatives.

The steps of the Fuzzy AHP methodology are summarized as follows.

- Define Fuzzy scale(triangular fuzzy)

- The procedure similar to the AHP process

- Calculate pair wise comparison matrices.

- Rank the strategies

By using the FAHP the global weight priorities are developed for sixteen measurement indicators. The Fuzzy scale[10,11,12] followed is shown in the table 1.The global weight for GP,GM,CS, EM are calculated by FAHP[6] and tabulated in table 5 for 
IOSR Journal of Engineering

Apr. 2012, Vol. 2(4) pp: 824-830

comparison purpose. The results obtained by using Fuzzy AHP for the parameters as GP(28.85) GM(34.6\%) CS(18.7\%) $\operatorname{EM}(17.9 \%)[6,7]$.

Table1. Scale for fuzzy pair-wise comparison.

\begin{tabular}{|c|l|l|}
\hline S.No & Scale values & $\begin{array}{l}\text { The relative importance of the } \\
\text { two sub-elements }\end{array}$ \\
\hline 1 & $0: 5$ & Equally important \\
\hline 2 & $0: 55($ or $0: 50: 6)$ & Slightly important \\
\hline 3 & $0: 65($ or $0: 60: 7)$ & Important \\
\hline 4 & $0: 75($ or $0: 70: 8)$ & Strongly important \\
\hline 5 & $0: 85($ or $0: 80: 9)$ & Very strongly important \\
\hline 6 & $0: 95($ or $0: 91: 0)$ & Extremely important \\
\hline
\end{tabular}

2.3 Fuzzy TOPSIS Approach: The TOPSIS (technique for order performance by similarity to ideal solution) is a solution to MCDM problem[13,14]. According to this technique, the best alternative would be the one that is nearest to the positive ideal solution (PIS) and farthest from the negative ideal solution (NIS). The PIS is a solution that maximizes the benefit criteria and minimizes the cost criteria and the NIS is vice versa. This paper extends TOPSIS to the fuzzy environment, which was introduced by Zadeh (1965) to map linguistic variables to numerical variables[15,16].

\subsection{TOPSIS Methodology}

Technique for of order preference by similarity to ideal solution(TOPSIS).In this paper the Green supply chain strategies are defined by AHP and TOPSIS.

This method consists of three types of attributes

- Qualitative benefits attributes

- Quantitative attributes benefits

- Cost attributes criteria

TOPSIS assumes that we have $\mathrm{m}$ alternatives (options) and $\mathrm{n}$ attributes and we have the score of each option with respect to each criterion

Step 1: Construct the normalized decision matrix a dn normalized scores are as follows $r_{i j}=X_{i j} /\left(\sum x_{i j}\right)$ for $i=1, \ldots, m ; j=1, \ldots$, $\mathrm{n}$ and for each indicator weights are taken from experts for a scale of 10 scores are shown in the table 2 
IOSR Journal of Engineering

Apr. 2012, Vol. 2(4) pp: 824-830

Table 2: Weight criteria allocation for Measurement Indicators

\begin{tabular}{|c|c|c|c|c|}
\hline Indicators & GP & GM & CS & EM \\
\hline $\mathrm{C} 1$ & 7 & 6 & 7 & 8 \\
\hline $\mathrm{C} 2$ & 6 & 7 & 6 & 7 \\
\hline $\mathrm{C} 3$ & 8 & 5 & 7 & 8 \\
\hline $\mathrm{C} 4$ & 6 & 7 & 6 & 8 \\
\hline $\mathrm{C} 5$ & 7 & 6 & 6 & 8 \\
\hline C6 & 8 & 7 & 7 & 8 \\
\hline $\mathrm{C} 7$ & 6 & 8 & 6 & 7 \\
\hline $\mathrm{C} 8$ & 7 & 7 & 7 & 8 \\
\hline $\mathrm{C} 9$ & 6 & 7 & 7 & 7 \\
\hline $\mathrm{C} 10$ & 6 & 8 & 7 & 8 \\
\hline $\mathrm{C} 11$ & 7 & 8 & 7 & 8 \\
\hline $\mathrm{C} 12$ & 5 & 7 & 6 & 7 \\
\hline $\mathrm{C} 13$ & 8 & 7 & 8 & 9 \\
\hline $\mathrm{C} 14$ & 7 & 7 & 8 & 7 \\
\hline $\mathrm{C} 15$ & 8 & 6 & 8 & 8 \\
\hline $\mathrm{C} 16$ & 7 & 6 & 8 & 8 \\
\hline$\left(\sum \mathbf{X}_{\mathrm{ij}}^{2}\right)$ & 755 & 753 & 779 & 966 \\
\hline$\left(\sum \mathbf{X}_{\mathrm{ij}}{ }^{2}\right)^{1 / 2}$ & 27.477 & 27.441 & 27.911 & 31.081 \\
\hline
\end{tabular}

Step 2: Constructt the weighted Normalized decision matrix.

Obtain the weights $\mathrm{Wj}$ where $\mathrm{J}=1 \ldots \mathrm{n}$ from Fuzzy AHP method and global weights $(\mathrm{Wj})$ are calculated they are $(28.85 \%, 34.6 \%, 18.7 \%, 17.9 \%)$ for GP, GM , CS, EM respectively

Then calculate the $\mathrm{V}_{\mathrm{ij}}=\mathrm{Wj} \mathrm{r}_{\mathrm{ij}}$. The weights are calculated by using Fuzzy AHP and results are tabulated in table 4.a and table $4 . b$ respectively.

Step 3.a: Determine the positive Ideal and negative Ideal Solution from Table 4.a and 4.b

- Ideal solution $\mathrm{A}^{*}=\left\{\mathrm{v}_{1}{ }^{*}, \ldots, \mathrm{v}_{\mathrm{n}}^{*}\right\}$, where

$$
\mathrm{v}_{\mathrm{j}}=\left\{\max \left(\mathrm{v}_{\mathrm{ij}}\right) \text { if } \mathrm{j} \in \mathrm{J} ; \min \left(\mathrm{v}_{\mathrm{ij}}\right) \text { if } \mathrm{j} \in \mathrm{J}^{\prime}\right\}
$$

The positive ideal solution is and

- Negative Ideal solution

$$
\mathrm{A}^{\prime}=\left\{\mathrm{v}_{1}^{\prime}, \ldots, \mathrm{v}_{\mathrm{n}}\right\} \text {, where }
$$

$v^{\prime}=\left\{\min \left(v_{i j}\right)\right.$ if $j \in J ; \max \left(v_{i j}\right)$ if $\left.j \in J^{\prime}\right\}$ 
IOSR Journal of Engineering Apr. 2012, Vol. 2(4) pp: 824-830

Table 3.a Calculation $V_{\mathrm{ij}}$ values

\begin{tabular}{|c|c|c|c|c|}
\hline Weight $\left(\mathbf{W}_{\mathbf{j}}\right)$ & $\mathbf{0 . 2 8 8}$ & $\mathbf{0 . 3 4 6}$ & $\mathbf{0 . 1 8 7}$ & $\mathbf{0 . 1 7 9}$ \\
\hline Indicators $\left(\mathrm{r}_{\mathrm{ij}}\right)$ & $\mathbf{G P}$ & $\mathbf{G M}$ & $\mathbf{C S}$ & $\mathbf{E M}$ \\
\hline $\mathrm{C} 1$ & 0.255 & 0.219 & 0.251 & 0.257 \\
\hline $\mathrm{C} 2$ & 0.218 & 0.255 & 0.215 & 0.225 \\
\hline $\mathrm{C} 3$ & 0.291 & 0.182 & 0.251 & 0.257 \\
\hline C4 & 0.218 & 0.255 & 0.215 & 0.257 \\
\hline C5 & 0.255 & 0.219 & 0.215 & 0.257 \\
\hline C6 & 0.291 & 0.255 & 0.251 & 0.257 \\
\hline C7 & 0.218 & 0.292 & 0.215 & 0.225 \\
\hline C8 & 0.255 & 0.255 & 0.251 & 0.257 \\
\hline C9 & 0.218 & 0.255 & 0.251 & 0.225 \\
\hline C10 & 0.218 & 0.292 & 0.251 & 0.257 \\
\hline C11 & 0.255 & 0.292 & 0.251 & 0.257 \\
\hline C12 & 0.182 & 0.255 & 0.215 & 0.225 \\
\hline C13 & 0.291 & 0.255 & 0.287 & 0.290 \\
\hline C14 & 0.255 & 0.255 & 0.287 & 0.225 \\
\hline C15 & 0.291 & 0.219 & 0.287 & 0.257 \\
\hline C16 & 0.255 & 0.219 & 0.287 & 0.257 \\
\hline
\end{tabular}

Table 3.b Determination of NIS and PIS

\begin{tabular}{|c|c|c|c|c|}
\hline Indicators & GP & GM & CS & EM \\
\hline C1 & 0.073 & 0.076 & 0.047 & 0.046 \\
\hline C2 & 0.063 & 0.088 & 0.040 & 0.040 \\
\hline C3 & 0.084 & 0.063 & 0.047 & 0.046 \\
\hline C4 & 0.063 & 0.088 & 0.040 & 0.046 \\
\hline C5 & 0.073 & 0.076 & 0.040 & 0.046 \\
\hline C6 & 0.084 & 0.088 & 0.047 & 0.046 \\
\hline C7 & 0.063 & $\mathbf{0 . 1 0 1}$ & 0.040 & 0.040 \\
\hline C8 & 0.073 & 0.088 & 0.047 & 0.046 \\
\hline C9 & 0.063 & 0.088 & 0.047 & 0.040 \\
\hline C10 & 0.063 & 0.101 & 0.047 & 0.046 \\
\hline C11 & 0.073 & 0.101 & 0.047 & 0.046 \\
\hline C12 & 0.052 & 0.088 & 0.040 & 0.040 \\
\hline C13 & 0.084 & 0.088 & 0.054 & 0.052 \\
\hline C14 & 0.073 & 0.088 & 0.054 & 0.040 \\
\hline C15 & 0.084 & 0.076 & 0.054 & 0.046 \\
\hline C16 & 0.073 & 0.076 & 0.054 & 0.046 \\
\hline
\end{tabular}


IOSR Journal of Engineering

Apr. 2012, Vol. 2(4) pp: 824-830

Step 4: Calculate separate measures for each alternative results are presented in table 3.b

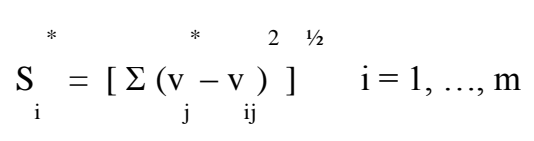

There fore positive Ideal solution $\mathrm{S}_{i}=(0.084,0.1,0.054,0.052)$

Similarly the separation from the negative ideal solution

$$
\mathrm{S}_{\mathrm{i}}^{\prime}=\left[\sum_{\mathrm{j}} \sum_{\mathrm{ij}}^{2} \mathrm{v}^{\prime}-\mathrm{v}^{\mathrm{1} / 2}\right]^{\mathrm{i}} \quad \mathrm{i}=1, \ldots, \mathrm{m}
$$

There fore Negative Ideal solution $S_{i}^{\prime}=(0.052,0.063,0.04,0.04)$

Step 5: Calculate the relative closeness to the Ideal solution $C_{i}^{*}$ and tabulated in table 4 .

Then select the option closeness to 1

$$
\mathrm{C}_{\mathrm{i}}=\mathrm{S}_{\mathrm{i}}^{\prime} /\left(\mathrm{S}_{\mathrm{i}}^{*}+\mathrm{S}^{\prime}\right), \quad 0<\mathrm{C}_{\mathrm{i}}<1
$$

\section{Results:}

In this present paper An Integrated fuzzy TOPSIS method is proposed and ranks are obtained for various Green Supply chain Strategies and priority weight for Green manufacturing is 58.765 followed by Green Purchasing with $57.83 \%$ and the results are compared with Fuzzy AHP method and results are tabulated in table 4. Green Supply chain management strategies using Fuzzy AHP and TOPSIS have shown that Green manufacturing has obtained the first rank and followed by Green Purchasing.

Table 4: Final ranking strategy from Fuzzy -TOPSIS approach

\begin{tabular}{|c|c|c|c|c|}
\hline $\begin{array}{l}\text { GSCM } \\
\text { Strategy }\end{array}$ & $\begin{array}{l}\text { Results from Positive } \\
\text { ideal solution(1) }\end{array}$ & $\begin{array}{l}\text { Results from negative } \\
\text { Ideal solution(2) }\end{array}$ & $\begin{array}{l}\text { Relative closeness } \\
\text { Determination(3=2/(1+2)) }\end{array}$ & $\begin{array}{l}\text { Rank } \\
\text { (4) }\end{array}$ \\
\hline GP & $\mathbf{0 . 0 6 2 5}$ & $\mathbf{0 . 0 8 5 7}$ & 0.5783 & 2 \\
\hline GM & 0.0696 & 0.0991 & 0.5876 & 1 \\
\hline CS & 0.0361 & 0.0335 & 0.4816 & 3 \\
\hline EM & 0.0322 & 0.022 & 0.4110 & 4 \\
\hline
\end{tabular}

\section{Conclusion:}

It is observed that from the comparison table 5, the results from both Fuzzy-AHP[6,17,18] and Fuzzy-Topsis for GSCM strategies gave the consistent ranking like other MCDM Models. Both these models gave highest rank to Green Manufacturing (GM), followed by Green Purchasing (GP).

Table 5: Comparison of results using FAHP and Fuzzy-TOPSIS

\begin{tabular}{|l|l|l|c|l|}
\hline SNO & $\begin{array}{l}\text { GSCM } \\
\text { Strategy }\end{array}$ & $\begin{array}{l}\text { Global using } \\
\text { FAHP }\end{array}$ & $\begin{array}{l}\text { Closeness values } \\
\text { form Fuzzy-TOPSIS }\end{array}$ & Rank \\
\hline 1 & GP & 0.288 & 0.578 & $\mathbf{2}$ \\
\hline 2 & GM & 0.346 & 0.587 & $\mathbf{1}$ \\
\hline 3 & CS & 0.187 & 0.481 & $\mathbf{3}$ \\
\hline 4 & EM & 0.179 & 0.411 & $\mathbf{4}$ \\
\hline
\end{tabular}


IOSR Journal of Engineering

Apr. 2012, Vol. 2(4) pp: 824-830

\section{References:}

[1] S Srivastava, "Green supply state of art literature review" International journal of management review, Vol 9(1) (2007), 53-80.

[2] P Muralidhar, K Ravindranath, V Srihari, "Perspective patterns of Environmental Green supply chain management" IJ-ETA-ETS Vol 3(2), (2010), 233-237.

[3] P Muralidhar , K Ravindranath , V Srihari V "Competitive strategies for Sustainable Supply Chain Management" -A case study Using AHP, Industrial Engineering Journal April 2(4) (2012) 24-27.

[4] T L. Saaty, The Analytic Hierarchy Process: Planning, Priority Setting, Resource allocation, Tata Mc Graw-Hill, (1980).

[5] T L Saaty,. Fundamentals of decision making and priority theory with AHP. RWS Publications, Pittsburg, (2000).

[6] P Muralidhar, K Ravindranath, V Srihari V "Application of Fuzzy AHP for Evaluation of Green Supply Chain Management Strategies" IOSR journal of Engineering. Vol 2(3), (2012), 461-467.

[7] $\mathrm{R}$ Venkata Rao,D Singh A hybrid multiple attribute decision making method for Solving Problems of industrial environment, International Journal of Industrial Engineering Computations,(2), (2011), 631-644.

[8] C Ninlawan, P Seksan, K Tossapol, and W Pilada, The Implementation of Green Supply chain Management Practices in Electronic Industry, Proceedings of International multy conference of Engineers and Computer scientists, Vol III, March (2010) 17-19, 2010 Hong Kong.

[9] ] Deng, S.J. and Elmaghraby, W. Supplier Selection via Tournaments. Production and Operations Management, Vol 4(2), (2005), 252-267.

[10] Van der Rhdd, b., Verma, R. and Plaschka G. Understanding trade-offs in the supplier selection process: The role of flexibility, delivery, and value added service/support. International Journal of Production Economics (in press) available online, 2009.

[11] Wanj Y J and lee H S and Lin K ., Fuzzy TOPSIS for Multi criteria decision- making" International Matahmatical journal Vol .3(4), (2003),367-379.

[12] Chan, F.T. S., Kumar, N., Tiwari, M. K., Lau, H.C. W. and Choy, K. L. Global supplier selection: a fuzzyAHP approach. International Journal of Production Research, (2007), 1 - 33.

[13] Wanj Y J and lee H S., "Generalizing the TOPSIS for Fuzzy for Multi criteria decision making" Computers and Mathematics with applications., Vol 53(11),(2007),1762-1772.

[14] Ertugtul I., Karakasoglu N. Comparison of fuzzy AHP and fuzzy TOPSIS methods for facility location selection. International Journal Adv MAnuf Technol. 2008.

[15] Tie-chin wang, hsien-da lee, Developing fuzzy TOPSIS approach based on subjective weights and objective weights[J] expert systems with applications, (36) (2009),8980-8985.

[16]

[17] Amid A., Ghodsypour S.H. and O'Brien C. A weighted additive fuzzy multiobjective model for the supplier selection problem under price breaks in supply chain. International Journal of Production Research, (in press, available online), 2009.

[18] Onut S., Kara S.S. and Isik E. Long-term supplier selection using a combined fuzzy MCDM approach:A case study for a telecommunication company. Expert systems with applications, (36), (2009) 38873895 . 